\title{
How to interpret lactate
}

\author{
Dilshad Marikar, ${ }^{1}$ Pratusha Babu, ${ }^{1}$ Miriam Fine-Goulden (1) ${ }^{2}$
}

- Additional material is published online only. To view please visit the journal online (http://dx.doi.org/10.1136/ archdischild-2020-319601).

${ }^{1}$ Paediatric Department, Addenbrooke's Hospital, Cambridge, UK

2Paediatric Intensive Care Unit, Evelina London Children's Hospital, Guy's \& St. Thomas' NHS Foundation Trust, London, UK

\section{Correspondence to} Dr Miriam Fine-Goulden, Paediatric Intensive Care, Evelina London Children's Hospital, London SE1 7EH, UK; miriam.finegoulden@gstt.nhs.uk

Accepted 22 July 2020 Published Online First 4 September 2020

\section{Check for updates}

(c) Author(s) (or their employer(s)) 2021. No commercial re-use. See rights and permissions. Published by BMJ.

To cite: Marikar D, Babu P, Fine-Goulden M. Arch Dis Child Educ Pract Ed 2021;106:167-171.

\begin{abstract}
The association between hyperlactataemia and poorer outcomes in acutely unwell adults and children is well recognised. Blood lactate testing has become readily available in acute settings and is considered a first-line investigation in international guidelines for the management of sepsis. However, while healthcare professionals do appreciate the value of measuring blood lactate in acute severe illness, its clinical significance and interpretation remain less well understood. In this paper, we present the evidence for the use of lactate as a diagnostic test and prognostic marker in acutely unwell children.
\end{abstract}

\section{BACKGROUND}

A widely held misconception is that lactate is a toxic waste product of metabolism, driven by hypoxia and/or hypoperfusion. ${ }^{1}$ It is now well established that increases in blood lactate due to hypoxia are likely the exception rather than the rule. ${ }^{1}$ At physiological $\mathrm{pH}$, lactic acid $\left(\mathrm{C}_{3} \mathrm{H}_{5} \mathrm{O}_{3}\right)$ is almost completely dissociated into lactate anions $\left(\mathrm{La}^{-}\right)$ and protons $\left(\mathrm{H}^{+}\right)$. In mitochondria, the process of glycolysis generates pyruvate from glucose. Pyruvate is converted to acetyl coenzyme A (Acetyl-CoA) by pyruvate dehydrogenase and enters the Krebs cycle to produce adenosine triphosphate (energy) (figure 1). The enzyme lactate dehydrogenase converts pyruvate to lactate, and, while the reaction goes both ways, the equilibrium is markedly in favour of lactate. Accelerated glycolysis (eg, in physiological stress) will always lead to an increase in lactate production, and lactate serves as a 'reservoir' supplying pyruvate to mitochondria. Lactate is shuttled within and between cells and organs where it is either oxidised to produce energy or converted back into glucose. Glucose can be stored as glycogen or released back into the circulation. Lactate itself is not toxic or harmful; indeed, there is some evidence that hyperlactataemia may be beneficial in some conditions, for example, traumatic brain injury and severe hypoglycaemia, and has a central role as a metabolic fuel. ${ }^{12}$

As for any metabolite, blood lactate concentration depends on the ratio between production and consumption. ${ }^{2}$ When elevated beyond baseline (0.3$1.8 \mathrm{mmol} / \mathrm{L})$, it is most often a sign of altered energy homeostasis, but this may be a physiologically appropriate adaptive response (figure 2).

The term 'lactate clearance' is often employed to refer to a fall in blood lactate level; however, this is misleading since changes in lactate levels depend both on lactate production and metabolism. ${ }^{2}$

That hyperlactataemia is associated with hypoxia, ischaemia and acidosis confounds its clinical interpretation, and a normal level should not offer reassurance in the face of other clinical concerns. $^{12}$

The assessment of hyperlactataemia in the context of inborn errors of metabolism is beyond the scope of this article; suggested resources are provided in box 1 .

\section{TECHNOLOGICAL BACKGROUND Sampling}

A venous blood lactate concentration of $<2 \mathrm{mmol} / \mathrm{L}$ is predictive of a (gold standard) arterial blood lactate of $<2 \mathrm{mmol} / \mathrm{L}$, but above this level an arterial sample is most reliable. ${ }^{3}$ Capillary blood lactate measured on heel-prick samples has been shown to correlate with arterial blood lactate in both preterm and term neonates. ${ }^{4}$ Though capillary blood gases are used extensively in paediatrics, there is insufficient evidence showing a correlation between capillary and either venous or arterial blood samples in children, and in adults, capillary lactate in acute illness has been shown to correlate poorly with venous lactate. ${ }^{5}$

\section{Analysing}

Blood lactate can be measured by pointof-care-testing (POCT) devices (using 
Glycolysis

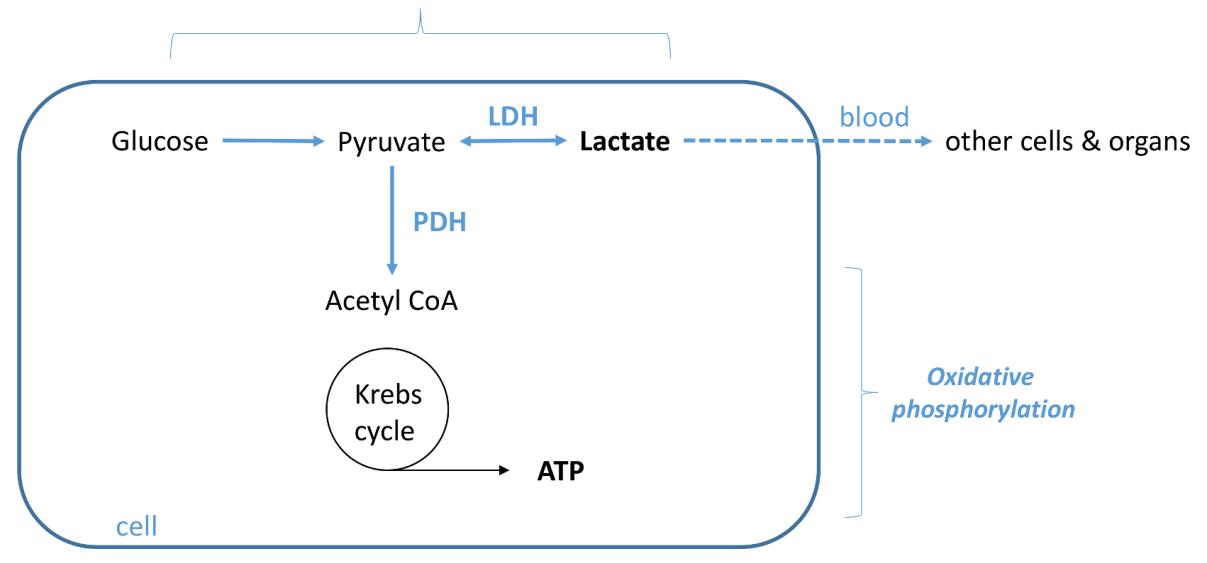

Figure 1 Lactate metabolism. LDH, lactate dehydrogenase; PDH, pyruvate dehydrogenase.

whole blood) or in the laboratory (on plasma). POCT requires smaller samples, can be performed on user-friendly instruments by staff without laboratory training, provides a rapid turnaround time for results and facilitates increased frequency of testing. ${ }^{6}$ Although there is generally a strong correlation between methods across the range of lactate values, at higher lactate concentrations POCT may be less reliable. ${ }^{7}$

\section{CLINICAL CASES}

In children with suspected sepsis does a raised blood lactate at presentation predict mortality?

Hyperlactataemia is correlated with increased mortality in studies of children and adults with sepsis; however, its definition (from 2 to $5 \mathrm{mmol} / \mathrm{L}$ ) and sampling timeframe (eg, initial lactate, peak lactate and/or duration of hyperlactataemia) varies. ${ }^{8}$
Intra-cellular lactate concentration

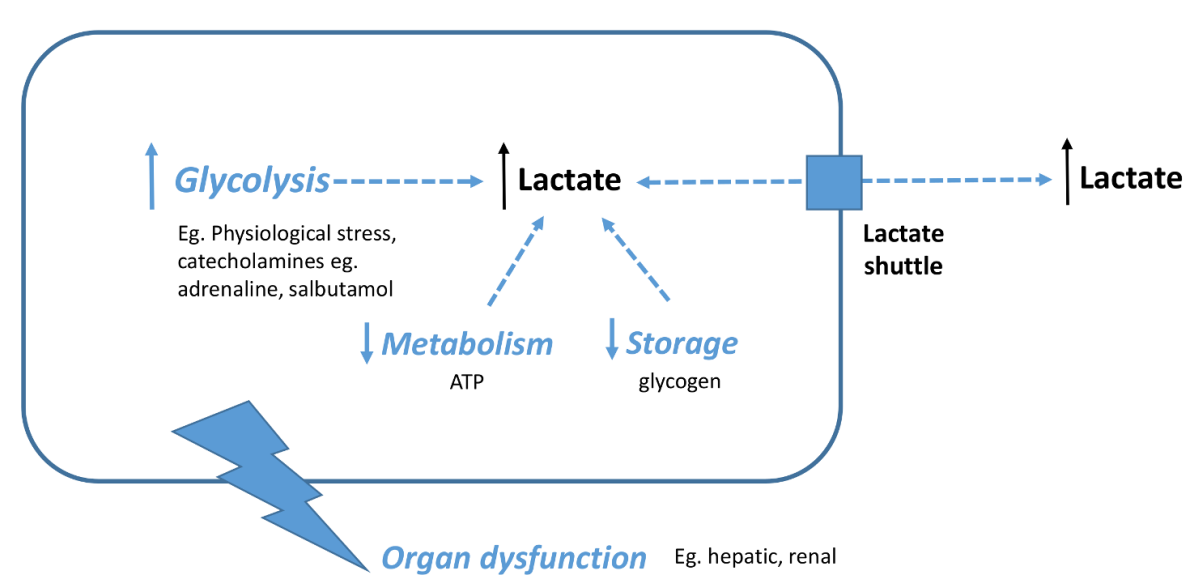

Figure 2 Elevated blood lactate concentration may be due to increased production, decreased consumption or changes in the balance of transport in and out of cells.

\section{Box 1 Inborn errors of metabolism-online}

\section{resources}

Vademecum Metabolicum (Assessment and Treatment of Inborn Errors of Metabolism): http://www.vademetab. org/

- British Inherited Metabolic Diseases Group (BIMDG) Emergency Guidelines: http://www.bimdg.org.uk/ guidelines/
Evidence for the accuracy of initial blood lactate in predicting mortality in children with sepsis is provided by several cohort studies; however, there is significant variation in patient populations and lactate thresholds (table 1). These studies demonstrate a large variation in mortality rates (from $1.9 \%$ in presentations to a USA emergency department (ED) to $63.5 \%$ for undifferentiated paediatric intensive care unit (PICU) admissions in 
Table 1 Diagnostic accuracy of initial blood lactate in predicting mortality in children with sepsis/suspected sepsis*

\begin{tabular}{|c|c|c|c|c|c|c|c|c|c|}
\hline Setting & Population & $\begin{array}{l}\text { Overall } \\
\text { mortality (\%) }\end{array}$ & $\begin{array}{l}\text { Lactate } \\
\text { cut-off } \\
\text { (mmol/L) }\end{array}$ & $\begin{array}{l}\text { Relative } \\
\text { risk of } \\
\text { death }\end{array}$ & Sensitivity & Specificity & PPV & NPV & $\begin{array}{l}\text { Mortality } \\
\text { timeframe }\end{array}$ \\
\hline $\mathrm{ED}(\text { USA })^{9}$ & $<18$ years $(n=1299)$ & 1.9 & $>4$ & 2.9 & $\begin{array}{l}20 \% \\
(12 \% \text { to } 28 \%)\end{array}$ & $\begin{array}{l}92.3 \% \\
(90.7 \% \text { to } \\
93.7 \%)\end{array}$ & $\begin{array}{l}4.85 \% \\
(2.23 \% \text { to } \\
10.26 \%)\end{array}$ & $\begin{array}{l}98.3 \% \\
(97.97 \% \text { to } \\
98.62 \%)\end{array}$ & 30 days \\
\hline $\begin{array}{l}\text { PICU admissions } \\
\text { (Europe) })^{13}\end{array}$ & 1 month to 18 years $(n=444)$ & 5.1 & $>2.2$ & 4.95 & $\begin{array}{l}78.1 \% \\
(56.3 \% \text { to } \\
92.5 \%)\end{array}$ & $\begin{array}{l}59.9 \% \\
(55 \% \text { to } 64.6 \%)\end{array}$ & $\begin{array}{l}9.6 \% \\
(7.7 \% \text { to } 12 \%)\end{array}$ & $\begin{array}{l}98.1 \% \\
(95.9 \% \text { to } \\
99.1 \%)\end{array}$ & $\begin{array}{l}\text { In-hospital } \\
\text { death or } \\
\text { survival }\end{array}$ \\
\hline $\begin{array}{l}\text { Hospital admissions } \\
\text { (East Africa) })^{11}\end{array}$ & $\begin{array}{l}60 \text { days to } 12 \text { years with } \\
\text { severe non-malarial febrile } \\
\text { illness }(n=1283)\end{array}$ & 12.4 & $>5$ & 5.82 & $\begin{array}{l}71.7 \% \\
(64 \text { to } 78.5 \%)\end{array}$ & $\begin{array}{l}75.5 \% \\
(72.9 \% \text { to } 78 \%)\end{array}$ & $\begin{array}{l}29.3 \\
(24.8 \% \text { to } \\
34.1 \%)\end{array}$ & $\begin{array}{l}95 \% \\
(93.3 \% \text { to } \\
96.3 \%)\end{array}$ & $72 \mathrm{~h}$ \\
\hline $\begin{array}{l}\text { Hospital admissions } \\
\text { (Uganda) }^{10}\end{array}$ & $\begin{array}{l}<5 \text { years with a diagnosis of } \\
\text { pneumonia }(n=155)\end{array}$ & 14 & $>3.4$ & 4.5 & $\begin{array}{l}68 \% \\
(45 \% \text { to } 86 \%)\end{array}$ & $\begin{array}{l}74 \% \\
(66 \% \text { to } 82 \%)\end{array}$ & $\begin{array}{l}31 \% \\
(23 \% \text { to } 40 \%)\end{array}$ & $\begin{array}{l}93 \% \\
(88 \% \text { to } 96 \%)\end{array}$ & 5 days \\
\hline 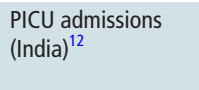 & 1 month to 12 years $(n=148)$ & 63.5 & $>4$ & 1.8 & $57 \%$ & $82 \%$ & $84 \%$ & $51 \%$ & $\begin{array}{l}\text { In-hospital } \\
\text { death or } \\
\text { survival }\end{array}$ \\
\hline
\end{tabular}

* $95 \%$ Cls provided where available in text or via author correspondence. PPV and NPV combine test accuracy and disease prevalence and as such can be misleading and can vary between patient groups, specifically where death rate PPV will appear poor even if the test is actually quite good.

NPV, negative predictive value; PPV, positive predictive value.

India), clearly representing significantly different populations. $^{9-13}$

In a large observational cohort study of 1299 children with suspected sepsis presenting to a US $\mathrm{ED},{ }^{9}$ those with initial lactate $>4 \mathrm{mmol} / \mathrm{L}$ had higher 30 -day mortality (4.8\% vs $1.7 \%)$. However, it is important to note that, in this patient group with a low mortality overall (1.9\%), 80\% (20/25) of all deaths were in children with initial lactate $<4 \mathrm{mmol} / \mathrm{L}$ and $>95 \%$ patients with lactate $>4 \mathrm{mmol} / \mathrm{L}$ survived, yielding a sensitivity of only $20 \%$. In a large study of children admitted to PICUs in Australia and New Zealand with sepsis and/or septic shock $(n=1697)$, mortality was independently correlated with lactate on presentation to ICU, with the highest mortality in children with hypotension requiring vasopressors and lactate $>2 \mathrm{mmol} / \mathrm{L}$ ( $32 \%$ vs $7.7 \%$ in the hypotensive nonvasopressor group with lactate $<2 \mathrm{mmol} / \mathrm{L}$ ). ${ }^{14}$

The recently published Surviving Sepsis Campaign (SSC) International Guidelines for the management of septic shock and sepsis-associated organ dysfunction in children, states: "we were unable to issue a recommendation about using blood lactate values to stratify children with suspected septic shock or other sepsis-associated organ dysfunction" and that levels should "be interpreted as part of a more comprehensive assessment of clinical status and perfusion" ${ }^{8}$ (see online supplementary infographic: decision-tree).

In children with suspected sepsis, does lowering lactate levels improve outcomes?

In adults with septic shock, there is some evidence that lactate-guided resuscitation reduces mortality though these findings remain under debate. ${ }^{1}$

In children, evidence for lactate as a therapeutic target is limited to observational studies ${ }^{10-12} 15$ table 2 .

In a cohort of 77 children presenting to a USA ED with suspected sepsis, those whose lactate normalised within 2 to 4 hours of presentation had

Table 2 Association between persistent hyperlactataemia and mortality*

\begin{tabular}{|c|c|c|c|c|c|c|c|c|c|}
\hline Setting & Population & $\begin{array}{l}\text { Overall } \\
\text { mortality (\%) }\end{array}$ & $\begin{array}{l}\text { Thresholds for lactate } \\
\text { reduction }\end{array}$ & $\begin{array}{l}\text { Relative } \\
\text { risk of } \\
\text { death }\end{array}$ & Sensitivity & Specificity & PPV & NPV & $\begin{array}{l}\text { Mortality } \\
\text { timeframe }\end{array}$ \\
\hline $\begin{array}{l}\text { Hospital } \\
\text { admissions (East } \\
\text { Africa) }\end{array}$ & $\begin{array}{l}60 \text { days to } 12 \text { years } \\
\text { with severe febrile } \\
\text { illness }(n=1906)\end{array}$ & 5.98 & $\begin{array}{l}\text { Failure to fall by } \geq 40 \% \\
\text { and/or lactate }>2.5 \mathrm{mmol} / \mathrm{L} \\
\text { at } 8 \mathrm{~h}\end{array}$ & 2.0 & $64 \%$ & $54.3 \%$ & $8.2 \%$ & $96 \%$ & $72 \mathrm{~h}$ \\
\hline $\begin{array}{l}\text { Hospital } \\
\text { admissions } \\
\text { (Uganda) }\end{array}$ & $\begin{array}{l}<5 \text { years with } \\
\text { a diagnosis of } \\
\text { pneumonia }(n=75)\end{array}$ & 17.33 & $\begin{array}{l}\text { Failure to fall by } \geq 40 \% \\
\text { by } 8 \mathrm{~h}\end{array}$ & 2.8 & $53.8 \%$ & $75.8 \%$ & $31.8 \%$ & $88.7 \%$ & $\begin{array}{l}\text { In-hospital } \\
\text { death or } \\
\text { survival }\end{array}$ \\
\hline 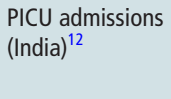 & $\begin{array}{l}1 \text { month to } 12 \text { years } \\
\text { with septic shock } \\
(n=148)\end{array}$ & 63.5 & $\begin{array}{l}\text { Failure to fall }>10 \% \text { from } \\
\text { baseline at } 24 \mathrm{~h}\end{array}$ & 2.5 & $\begin{array}{l}78.7 \% \\
(68.8 \% \text { to } \\
86.2 \%)\end{array}$ & $\begin{array}{l}72.2 \% \\
(58.1 \% \text { to } \\
83.1 \%)\end{array}$ & $\begin{array}{l}83.1 \% \\
(73.4 \% \text { to } \\
89.9 \%)\end{array}$ & $\begin{array}{l}66.1 \% \\
(52.5 \% \text { to } \\
77.5 \%)\end{array}$ & $\begin{array}{l}\text { In-hospital } \\
\text { death or } \\
\text { survival }\end{array}$ \\
\hline 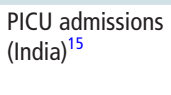 & $\begin{array}{l}1 \text { month to } 17 \text { years } \\
\text { with septic shock } \\
(n=112)\end{array}$ & 31.3 & $\begin{array}{l}\text { Failure to fall }>20 \% \text { from } \\
\text { baseline at } 24 \mathrm{~h}\end{array}$ & 12.1 & $92 \%$ & $63 \%$ & $84.5 \%$ & $78.6 \%$ & 60 days \\
\hline
\end{tabular}

${ }^{*} 95 \%$ Cls provided (in brackets) where available in text or via author correspondence.

NPV, negative predictive value; PPV, positive predictive value. 
decreased risk of organ dysfunction at 48 hours (RR 0.46, 0.29-0.73). ${ }^{16}$

In a study of Ugandan children admitted to hospital with pneumonia with lactate $>2.5 \mathrm{mmol} / \mathrm{L}$, mortality was increased in those whose levels remained $\geq 40 \%$ baseline by 8 hours (32\% vs $11 \%$, $\mathrm{p}=0.046){ }^{\frac{70}{10}}$

Persistent hyperlactataemia may be more predictive of mortality than raised admission lactate. In a study of 700 medical PICU admissions, ${ }^{17}$ persistent hyperlactataemia ( $>2 \mathrm{mmol} / \mathrm{L}$ ) at 24 hours was associated with $93 \%$ mortality versus $30 \%$ in children whose lactate levels normalised (sensitivity $78 \%$, specificity $89 \%, L R+7, L R-0.25)$; this compared with $64 \%$ mortality in children with admission hyperlactataemia versus $6 \%$ in children without. Two studies address persistent hyperlactataemia at 24 hours in children with septic shock admitted to PICUs in India: Choudhary et al $(\mathrm{n}=148)$ observed that lactate levels falling $<10 \%$ were associated with $83.1 \%(74 / 89)$ mortality versus $33.9 \%$ $(20 / 59)$ in children whose lactate normalised more rapidly ${ }^{12}$; Nazir et al reported that children whose lactate failed to fall by $>20 \%$ at 24 hours had $100 \%(28 / 28) 60$-day mortality versus $8.3 \%(7 / 84)$ in those whose lactate reduced by $\geq 20 \% .{ }^{15}$ This association was evident even at 6 hours: mortality $83.3 \%$ versus $17.05 \%$ (sensitivity $94.8 \%$, specificity $57.1 \%, \mathrm{LR}+2.21, \mathrm{LR}-0.091)$.

It is important to note that, since these studies are observational and not interventional, there is currently insufficient evidence to support the use of lactate as a therapeutic target in paediatric sepsis. However, there is an association between persistent hyperlactataemia and mortality and morbidity, so failure of lactate levels to normalise is likely to be a valuable indicator of disease severity.

SSC guidelines suggest-as a weak recommendation, with very low quality of evidence-"using trends in blood lactate levels, in addition to clinical assessment, to guide resuscitation" and note that "a persistent elevation in blood lactate may indicate incomplete haemodynamic resuscitation and should prompt efforts, as needed, to further promote hemodynamic stability". 8

In neonates in neonatal intensive care, do lactate levels on day 1 of life predict morbidity and/or mortality?

Hyperlactataemia in the neonatal period may represent an acute insult or underlying disease such as inborn error of metabolism.

In suspected neonatal hypoxic ischaemic encephalopathy (HIE), there is an association with hyperlactataemia as a marker of secondary energy failure. In a retrospective study of 61 term neonates, a plasma lactate $>7.5 \mathrm{mmol} / \mathrm{L}$ within 1 hour of life was associated with moderate or severe HIE-sensitivity 94\% (PPV 55\%) and specificity 67\% (NPV 97\%). ${ }^{18}$
A study of admission and peak lactate in the first 12 hours of life in low birthweight and preterm neonates $(n=381)$ reported an association between hyperlactataemia and in-hospital mortality, which was also independently associated with abnormal cranial ultrasound scans, bronchopulmonary dysplasia and retinopathy of prematurity. ${ }^{19}$

In neonates requiring extracorporeal membrane oxygenation (mainly for respiratory pathology such as meconium aspiration, congenital diaphragmatic hernia and persistent pulmonary hypertension), a prospective study $(n=74)$ found admission, 12 hours and peak lactate levels were significantly higher in non-survivors, but only peak levels $(>15 \mathrm{mmol} / \mathrm{L})$ were associated with poorer neurodevelopmental outcome at 2 years. ${ }^{20}$

\section{In neonates with suspected necrotising enterocolitis (NEC), is lactate useful as a diagnostic or prognostic marker?}

A small retrospective study $(n=24)$ evaluated the prognostic value of perioperative measurement of blood lactate levels for neonates undergoing surgery for NEC; those with lactate $>1.6 \mathrm{mmol} / \mathrm{L}$ were more likely to develop complications such as strictures and death. ${ }^{21}$ Serial changes in lactate are better predictors of progression in confirmed NEC. A cohort study $(\mathrm{n}=37)$ comparing lactate level changes from baseline over 48 hours in preterm neonates with medical and surgical management of NEC showed that a rise from baseline at 72 hours was associated with progression to surgical intervention or mortality (area under the curve (AUC) $0.82, p=0.047)$, though in this group, a rise in $C$ reactive protein showed a stronger association (AUC 0.93, p=0.001). ${ }^{22}$

Despite a widely held belief by clinicians that an increased lactate level is associated with an increased likelihood of NEC, ${ }^{23}$ there is currently

\section{Clinical bottom line}

Lactate is an important molecule with complex biological functions-it is not a simple marker of hypoxia or a waste product of metabolism.

- Elevated lactate levels indicate a metabolic imbalance between production, consumption and cellular transport.

- A normal lactate at presentation does not rule out severe sepsis or septic shock and should not be considered reassuring in the presence of adverse clinical signs.

> In sepsis, a high blood lactate at presentation should prompt careful monitoring, as persistent hyperlactataemia is associated with organ dysfunction and mortality.

- Elevated lactate does not assist in the diagnosis of necrotising enterocolitis (NEC), but in neonates with confirmed NEC, hyperlactataemia is associated with poorer outcomes. 
insufficient evidence to support the use of lactate as a diagnostic marker for the disease.

Twitter Dilshad Marikar @MDMarikar, Pratusha Babu @docpbabu and Miriam Fine-Goulden@finegoulden

Acknowledgements Drs A Arumburo, H F Scott and NP Boeddha for providing clarifying information.

Contributors DM and PB: initial manuscript draft. MF-G, DM and PB: manuscript revisions. PB and MF-G produced the figures and DM the infographic. DM produced statistical summary tables. This is an update of an article originally published in ADCE\&P by MF-G in 2014.

Funding The authors have not declared a specific grant for this research from any funding agency in the public, commercial or not-for-profit sectors.

Competing interests None declared.

Patient consent for publication Not required.

Provenance and peer review Commissioned; externally peer reviewed.

ORCID iD

Miriam Fine-Goulden http://orcid.org/0000-0002-4247-6803

\section{REFERENCES}

1 Ferguson BS, Rogatzki MJ, Goodwin ML, et al. Lactate metabolism: historical context, prior misinterpretations, and current understanding. Eur J Appl Physiol 2018;118:691-728.

2 Hernandez G, Bellomo R, Bakker J. The ten pitfalls of lactate clearance in sepsis. Intensive Care Med 2019;45:82-5.

3 Samaraweera SA, Gibbons B, Gour A, et al. Arterial versus venous lactate: a measure of sepsis in children. Eur J Pediatr 2017; 176:1055-60.

4 Fauchère J-C, Bauschatz AS, Arlettaz R, et al. Agreement between capillary and arterial lactate in the newborn. Acta Paediatr 2007;91:78-81.

5 Graham CA, Leung LY, Lo RS, et al. Agreement between capillary and venous lactate in emergency department patients: prospective observational study. BMJ Open 2019;9:e026109.

6 Shaw JLV. Practical challenges related to point of care testing. Pract Lab Med 2016;4:22-9.

7 Karon BS, Scott R, Burritt MF, et al. Comparison of lactate values between point-of-care and central laboratory analyzers. Am J Clin Pathol 2007;128:168-71.

8 Weiss SL, Peters MJ, Alhazzani W, et al. Surviving Sepsis Campaign International Guidelines for the Management of Septic Shock and Sepsis-Associated Organ Dysfunction in Children. Pediatric Critical Care Medicine 2020;21:e52-106.

9 Scott HF, Brou L, Deakyne SJ, et al. Association between early lactate levels and 30-day mortality in clinically suspected sepsis in children. JAMA Pediatr 2017;171:249-55.

$10 \mathrm{Ma}$ C, Gunaratnam LC, Ericson A, et al. Handheld point-of-care lactate measurement at admission predicts mortality in Ugandan children hospitalized with pneumonia: a prospective cohort study. Am J Trop Med Hyg 2019;100:37-42.

11 Aramburo A, Todd J, George EC, et al. Lactate clearance as a prognostic marker of mortality in severely ill febrile children in East Africa. BMC Med 2018;16:37.

12 Choudhary R, Sitaraman S, Choudhary A. Lactate clearance as the predictor of outcome in pediatric septic shock. J Emerg Trauma Shock 2017;10:55-9.

13 Boeddha NP, Schlapbach LJ, Driessen GJ, et al. Mortality and morbidity in community-acquired sepsis in European pediatric intensive care units: a prospective cohort study from the European Childhood Life-threatening Infectious Disease Study (EUCLIDS). Crit Care 2018;22:143.

14 Schlapbach LJ, MacLaren G, Festa M, et al. Prediction of pediatric sepsis mortality within $1 \mathrm{~h}$ of intensive care admission. Intensive Care Med 2017;43:1085-96.

15 Nazir M, Wani W, Dar SA, et al. Lactate clearance prognosticates outcome in pediatric septic shock during first $24 \mathrm{~h}$ of intensive care unit admission. J Intensive Care Soc 2019;20:290-8.

16 Scott HF, Brou L, Deakyne SJ, et al. Lactate clearance and normalization and prolonged organ dysfunction in pediatric sepsis. J Pediatr 2016;170:149-55.

17 Hatherill M, McIntyre AG, Wattie M, et al. Early hyperlactataemia in critically ill children. Intensive Care Med 2000;26:314-8.

18 Shah S, Tracy M, Smyth J. Postnatal lactate as an early predictor of short-term outcome after intrapartum asphyxia. $J$ Perinatol 2004;24:16-20.

19 Phillips LA, Dewhurst CJ, Yoxall CW. The prognostic value of initial blood lactate concentration measurements in very low birthweight infants and their use in development of a new disease severity scoring system. Arch Dis Child Fetal Neonatal Ed 2011;96:F275-80.

20 Cheung P-Y, Etches PC, Weardon M, et al. Use of plasma lactate to predict early mortality and adverse outcome after neonatal extracorporeal membrane oxygenation: a prospective cohort in early childhood. Crit Care Med 2002;30:2135-9.

21 Abubacker M, Yoxall CW, Lamont G. Peri-operative blood lactate concentrations in pre-term babies with necrotising enterocolitis. Eur J Pediatr Surg 2003;13:35-9.

22 Srinivasjois R, Nathan E, Doherty D, et al. Prediction of progression of definite necrotising enterocolitis to need for surgery or death in preterm neonates. J Matern Fetal Neonatal Med 2010;23:695-700.

23 Valpacos M, Arni D, Keir A, et al. Diagnosis and management of necrotizing enterocolitis: an international survey of neonatologists and pediatric surgeons. Neonatology 2018;113:170-6. 